\title{
EPIDEMIOLOGY OF ACUTE POISONINGS DURING 2003-2007 IN TOXICOLOGY UNIT, DEPARTMENT OF OCCUPATIONAL MEDICINE AND TOXICOLOGY, NOFER INSTITUTE OF OCCUPATIONAL MEDICINE, ŁÓDŹ, POLAND
}

\author{
ANNA KRAKOWIAK ${ }^{1}$, MAŁGORZATA KOTWICA ${ }^{2}$, KONRAD ŚLIWKIEWICZ ${ }^{1}$, \\ and ANNA PIEKARSKA-WIJATKOWSKA ${ }^{2}$ \\ ${ }^{1}$ Nofer Institute of Occupational Medicine, Łódź, Poland \\ Toxicology Unit, Department of Occupational Diseases and Toxicology \\ ${ }^{2}$ Nofer Institute of Occupational Medicine, Łódź, Poland \\ National Poison Information Centre
}

\begin{abstract}
Objectives: The epidemiology of acute poisonings, observed in Toxicology Unit in Łódź, is the main objective of the study. The authors present frequency of respective kinds of poisoning cases and associated mortality. They discuss also the structure of poisonings with regard to type and causative agents over a period between 2003 and 2007. Materials and methods: The data used for the analysis were obtained from National Poison Information Center in Łódź. They were divided into two groups. The first one comprised information about patients treated at the Toxicology Unit (TU), whereas the other one included cases treated in other hospitals and only consulted by TU staff. Results: Analysis of the data shows that overdosage of medications was the most frequent cause of hospitalization during 2006-2007. It constituted also the leading cause of deaths due to poisoning during 2003-2005. However, it was superseded during the subsequent period of 2006-2007 by intoxication with alcohols which was associated with the highest number of deaths in the latter period. Situation changed dynamically also with regard to the intention of poisoning. Suicidal poisonings constituted the largest group in 2003, whereas poisonings caused by abuse, including dependence-related abuse, were the most frequent in subsequent years. Patients between 15 and 30 years old formed the largest group among the total number of poisonings. Conclusions: The results of our study on epidemiology of acute poisoning in Łódź between 2003-2007 show that poisoning is a frequent cause of admission to hospital and constitutes a major health problem in Łódź district because of large number of hospital admissions, associated mortality and the high proportion of patients at young age.
\end{abstract}

Key words:

Poisonings, Epidemiology, Statistics, Łódź, Poland

Received: January 14, 2011. Accepted: March 1, 2011.

Address reprint request to A. Krakowiak, Toxicology Unit, Department of Occupational Diseases and Toxicology, Nofer Institute of Occupational Medicine, św. Teresy 8 , 91-348 Łódź, Poland (e-mail: annakrak@imp.lodz.pl). 


\section{INTRODUCTION}

Poisonings are responsible for a significant part of hospital admissions and therefore, but also due to associated mortality and their high prevalence in the population of young people, they are considered to be a major health problem. Results of other epidemiologic studies show that problem clearly.

Poisonings only accounted for 924626 Emergency department (ED) admissions in USA during 2006 [1]. Brvar et al. revealed that the percentage of patients treated in ED due to intentional medication overdosage was as high as $1.3 \%$ (13/1000) [2]. A study carried out in Oslo in 1980 showed that incidence of hospitalizations caused by self-poisonings was 280 per 1000000 [3]. Authors from Milan Poison Control Center, which handles about $60 \%$ of enquiries in the area of human intoxications from Italy, registered 42483 new cases of human exposure to poisons in 2005 [4]. Eighty three per cent of poisonings reported in this study was caused by pharmaceuticals and $14 \%$ by non pharmaceuticals. Important finding in this report is the significant proportion of suicidal attempts that reached $19 \%$ of total cases.

The present study presents epidemiology of acute poisonings during 2003-2007 in Łódź. The authors show the frequency of poisonings and their distribution with reference to particular groups of toxic agents, patients' gender and age.

\section{MATERIALS AND METHODS}

This work is based on the statistical data gathered by staff of National Poison Information Center (NPIC) during 20032007. The data may be classified into two categories. The first category applies to patients treated at the Toxicology Unit (TU), whereas the other one refers to TU staff-consulted cases treated in other hospitals without dedicated toxicology units.

\section{RESULTS}

The number of patients treated in TU showed a rising tendency during first three years of the reported

Table 1. Statistical data, Łódź, 2003

\begin{tabular}{|c|c|c|c|c|}
\hline Toxic factor & $\begin{array}{l}\text { Deaths } \\
\text { (n) }\end{array}$ & $\begin{array}{c}\text { Consulted } \\
\text { patients } \\
(\mathrm{n}) \\
\end{array}$ & $\begin{array}{c}\text { Patients treated } \\
\text { in TU } \\
\text { (n) }\end{array}$ & $\begin{array}{c}\text { Total } \\
\text { (n) }\end{array}$ \\
\hline Medications & 5 & 353 & 1158 & 1511 \\
\hline Pesticides & - & 93 & 6 & 99 \\
\hline Alcohols & 1 & 38 & 488 & 526 \\
\hline Glycols & - & 8 & 13 & 21 \\
\hline Gases (including CO) & 1 & $24(14)$ & $155(138)$ & $179(152)$ \\
\hline Drugs of abuse & - & 22 & 123 & 145 \\
\hline Solvents & - & 70 & 29 & 99 \\
\hline Corrosives & - & 67 & 27 & 94 \\
\hline Detergents & - & 12 & 2 & 14 \\
\hline Metals & - & 12 & - & 12 \\
\hline Mushrooms (including Amanita phalloides) & - & $19(3)$ & 13 & $32(3)$ \\
\hline Toxic plants & - & 10 & 1 & 11 \\
\hline Venoms & - & 2 & 2 & 4 \\
\hline Others & 2 & 38 & 8 & 46 \\
\hline Unknown & - & - & 131 & 131 \\
\hline Suspicion of poisoning & - & 44 & - & 44 \\
\hline Poisoning ruled out & - & 3 & 76 & 79 \\
\hline Total & 9 & 815 & 2232 & 3047 \\
\hline
\end{tabular}


Table 2. Statistical data, Łódź, 2004

\begin{tabular}{|c|c|c|c|c|}
\hline Toxic factor & $\begin{array}{l}\text { Deaths } \\
\text { (n) }\end{array}$ & $\begin{array}{l}\text { Consulted } \\
\text { patients } \\
\text { (n) }\end{array}$ & $\begin{array}{l}\text { Patients treated } \\
\text { in TU } \\
\text { (n) }\end{array}$ & $\begin{array}{l}\text { Total } \\
\text { (n) }\end{array}$ \\
\hline Medications & 8 & 262 & 1174 & 1436 \\
\hline Pesticides & - & 56 & 3 & 59 \\
\hline Alcohols & 1 & 29 & 613 & 642 \\
\hline Glycols & 2 & 13 & 16 & 29 \\
\hline Gases (including CO) & $2(2)$ & $17(8)$ & $189(184)$ & $206(192)$ \\
\hline Drugs of abuse & - & 15 & 133 & 148 \\
\hline Solvents & - & 37 & 23 & 60 \\
\hline Corrosives & 1 & 45 & 19 & 64 \\
\hline Detergents & - & 4 & - & 4 \\
\hline Metals & - & 3 & 8 & 11 \\
\hline Mushrooms (including Amanita phalloides) & - & $26(2)$ & 11 & $37(2)$ \\
\hline Toxic plants & - & 10 & - & 10 \\
\hline Venoms & - & 6 & 2 & 8 \\
\hline Others & - & 25 & 5 & 30 \\
\hline Unknown & - & - & 131 & 131 \\
\hline Suspicion of poisoning & - & 43 & - & 43 \\
\hline Poisoning ruled out & - & - & 43 & 43 \\
\hline Total & 14 & 591 & 2370 & 2961 \\
\hline
\end{tabular}

Table 3. Statistical data, Łódź, 2005

\begin{tabular}{|c|c|c|c|c|}
\hline Toxic factor & $\begin{array}{l}\text { Deaths } \\
\text { (n) }\end{array}$ & $\begin{array}{l}\text { Consulted } \\
\text { patients } \\
\text { (n) }\end{array}$ & $\begin{array}{l}\text { Patients treated } \\
\text { in TU } \\
\text { (n) }\end{array}$ & $\begin{array}{l}\text { Total } \\
\text { (n) }\end{array}$ \\
\hline Medications & 4 & 298 & 1205 & 1503 \\
\hline Pesticides & - & 83 & 7 & 90 \\
\hline Alcohols & 1 & 52 & 870 & 922 \\
\hline Glycols & 1 & 7 & 14 & 21 \\
\hline Gases (including CO) & - & $19(10)$ & $174(171)$ & $193(181)$ \\
\hline Drugs of abuse & - & 22 & 138 & 160 \\
\hline Solvents & - & 49 & 20 & 69 \\
\hline Corrosives & - & 57 & 10 & 67 \\
\hline Detergents & - & 4 & 3 & 7 \\
\hline Metals & - & 10 & 1 & 11 \\
\hline Mushrooms (including Amanita phalloides) & - & $14(3)$ & 17 & $31(3)$ \\
\hline Toxic plants & - & 4 & - & 4 \\
\hline Venoms & - & 2 & - & 2 \\
\hline Others & - & 34 & 11 & 45 \\
\hline Unknown & - & - & 160 & 160 \\
\hline Suspicion of poisoning & - & 61 & - & 61 \\
\hline Poisoning ruled out & - & 5 & 24 & 29 \\
\hline Total & 6 & 721 & 2654 & 3375 \\
\hline
\end{tabular}


Table 4. Statistical data, Łódź, 2006

\begin{tabular}{|c|c|c|c|c|}
\hline Toxic factor & $\begin{array}{l}\text { Deaths } \\
\text { (n) }\end{array}$ & $\begin{array}{l}\text { Consulted } \\
\text { patients } \\
\text { (n) }\end{array}$ & $\begin{array}{l}\text { Patients treated } \\
\text { in TU } \\
\text { (n) }\end{array}$ & $\begin{array}{c}\text { Tota } \\
\text { (n) }\end{array}$ \\
\hline Medications & 6 & 268 & 943 & 1211 \\
\hline Pesticides & 1 & 68 & 5 & 73 \\
\hline Alcohols & 8 & 54 & 523 & 577 \\
\hline Glycols & 1 & 14 & 12 & 26 \\
\hline Gases (including CO) & - & $18(14)$ & $177(173)$ & 195 \\
\hline Drugs of abuse & 1 & 10 & 83 & 93 \\
\hline Solvents & - & 43 & 19 & 62 \\
\hline Corrosives & - & 56 & 21 & 77 \\
\hline Detergents & - & 3 & 2 & 5 \\
\hline Metals & - & 3 & - & 3 \\
\hline Mushrooms (including Amanita phalloides) & - & $32(1)$ & $35(1)$ & 67 \\
\hline Toxic plants & - & 4 & - & 4 \\
\hline Venoms & - & 3 & 4 & 7 \\
\hline Others & - & 18 & 9 & 27 \\
\hline Unknown & - & - & 53 & 53 \\
\hline Suspicion of poisoning & - & 50 & - & 50 \\
\hline Poisoning ruled out & - & 2 & 3 & 5 \\
\hline Total & 17 & 646 & 1889 & 2535 \\
\hline
\end{tabular}

Table 5. Statistical data, Łódź, 2007

\begin{tabular}{|c|c|c|c|c|}
\hline Toxic factor & $\begin{array}{l}\text { Deaths } \\
\text { (n) }\end{array}$ & $\begin{array}{c}\text { Consulted } \\
\text { patients } \\
(\mathrm{n})\end{array}$ & $\begin{array}{c}\text { Patients treated } \\
\text { in TU } \\
\text { (n) }\end{array}$ & $\begin{array}{c}\text { Tota } \\
\text { (n) }\end{array}$ \\
\hline Medications & 1 & 220 & 635 & 855 \\
\hline Pesticides & 1 & 54 & 3 & 57 \\
\hline Alcohols & 3 & 50 & 339 & 389 \\
\hline Glycols & - & 4 & 11 & 15 \\
\hline Gases (including CO) & - & $11(3)$ & $130(128)$ & 141 \\
\hline Drugs of abuse & - & 12 & 50 & 62 \\
\hline Solvents & - & 37 & 9 & 46 \\
\hline Corrosives & - & 36 & 10 & 46 \\
\hline Detergents & - & 8 & 1 & 9 \\
\hline Metals & - & 9 & - & 9 \\
\hline Mushrooms (including Amanita phalloides) & - & $20(1)$ & 31 & 51 \\
\hline Toxic plants & - & 9 & - & 9 \\
\hline Venoms & - & 3 & 2 & 5 \\
\hline Others & - & 12 & - & 12 \\
\hline Unknown & 2 & - & 20 & 20 \\
\hline Suspicion of poisoning & - & 42 & - & 42 \\
\hline Poisoning ruled out & - & 4 & 3 & 7 \\
\hline Total & 7 & 531 & 1244 & 1775 \\
\hline
\end{tabular}


period, with 2232 hospital admissions in 2003, 2370 in 2004 and 2654 in 2005, respectively. Surprisingly, it fell abruptly during the next two years to 1889 admissions in 2006 and 1244 in 2007 (Table 1-5).

The number of telephone enquiries changed during the reported period, showing a declining tendency, with 815 information pieces in 2003, 591 - in 2004, 721 - in 2005, 646 - in 2006 and 531 - in 2007 (Table 1-5).

Total number of poisoned patients (pts) during 2003-2004, including those treated in TU and the ones only consulted by phone, remained at rather steady level with 3047 pts in 2003 and 2961 in 2004, respectively. It increased up to 3375 in 2005, whereas during 2006-2007 subsequently decreased to 2535 pts in 2006 and 1775 in 2007. Number of cases treated in TU is shown in Figure 1. Causes of acute poisonings in TU during 2003-2007 are presented in Tables 1-6.

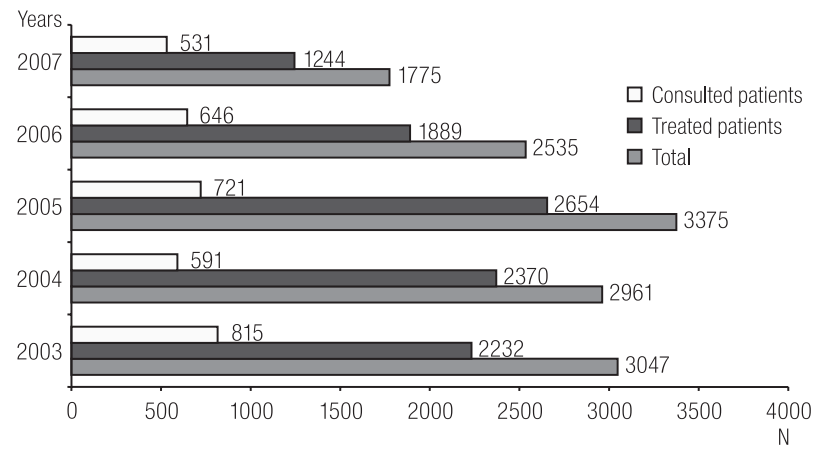

Fig. 1. Poisonings in Łódź, 2003-2007.

Analysis of registered data revealed that medications were the most frequent causative agents, accounting for $49.6 \%$ of total cases of recorded poisonings in 2003, $48.5 \%$ in 2004, $44.6 \%$ in 2006, $47.8 \%$ in 2006 and $48.2 \%$ in 2007 (Table 6).

They were followed by poisonings with alcohols, that were responsible for $17.3 \%$ of registered cases in 2003,

Table 6. Statistical data, Łódź, 2003-2007

\begin{tabular}{lrrrrrrrrrr}
\hline \multirow{2}{*}{ Toxic factor } & \multicolumn{2}{c}{2003} & \multicolumn{2}{c}{2004} & \multicolumn{2}{c}{2005} & \multicolumn{2}{c}{2006} & \multicolumn{2}{c}{2007} \\
\cline { 2 - 11 } \multicolumn{1}{c}{} & \multicolumn{1}{c}{ n } & \multicolumn{1}{c}{$\mathrm{n}$} & \multicolumn{1}{c}{$\%$} & \multicolumn{1}{c}{$\mathrm{n}$} & \multicolumn{1}{c}{$\mathrm{n}$} & \multicolumn{1}{c}{$\%$} & $\mathrm{n}$ & $\%$ \\
\hline Medications & 1511 & 49.6 & 1436 & 48.5 & 1503 & 44.6 & 1211 & 47.8 & 855 & 48.2 \\
Pesticides & 99 & 3.2 & 59 & 2.0 & 90 & 2.7 & 73 & 2.9 & 57 & 3.2 \\
Alcohols & 526 & 17.3 & 642 & 21.7 & 922 & 27.4 & 577 & 22.8 & 389 & 21.9 \\
Glycols & 21 & 0.7 & 29 & 1.0 & 21 & 0.6 & 26 & 1.0 & 15 & 0.8 \\
Gases (including CO) & 179 & 5.9 & 206 & 7.0 & 193 & 5.7 & 195 & 7.7 & 141 & 7.9 \\
Drugs of abuse & 145 & 4.8 & 148 & 5.0 & 160 & 4.7 & 93 & 3.7 & 62 & 3.5 \\
Solvents & 99 & 3.2 & 60 & 2.0 & 69 & 2.0 & 62 & 2.4 & 46 & 2.6 \\
Corrosives & 94 & 3.1 & 64 & 2.1 & 67 & 2.0 & 77 & 3.0 & 46 & 2.6 \\
Detergents & 14 & 0.5 & 4 & 0.1 & 7 & 0.2 & 5 & 0.2 & 9 & 0.5 \\
Metals & 12 & 0.4 & 11 & 0.4 & 11 & 0.3 & 3 & 0.1 & 9 & 0.5 \\
Mushrooms (including & 32 & 1.1 & 37 & 1.2 & 31 & 0.9 & 67 & 2.6 & 51 & 2.8 \\
$\quad$ Amanita phalloides) & & & & & & & & & & \\
Toxic plants & 11 & 0.4 & 10 & 0.3 & 4 & 0.1 & 4 & 0.2 & 9 & 0.5 \\
Venoms & 4 & 0.1 & 8 & 0.3 & 2 & 0.1 & 7 & 0.3 & 5 & 0.3 \\
Others & 46 & 1.5 & 30 & 1.0 & 45 & 1.3 & 27 & 1.0 & 12 & 0.7 \\
Unknown & 131 & 4.3 & 131 & 4.4 & 160 & 4.7 & 53 & 2.1 & 20 & 1.1 \\
Suspition of poisoning & 44 & 1.4 & 43 & 1.5 & 61 & 1.8 & 50 & 2.0 & 42 & 2.5 \\
Poisoning ruled out & 79 & 2.6 & 43 & 1.5 & 29 & 0.9 & 5 & 0.2 & 7 & 0.4 \\
Total & 3047 & 100.0 & 2961 & 100.0 & 3375 & 100.0 & 2535 & 100.0 & 1775 & 100.0 \\
\hline
\end{tabular}


$21.7 \%$ in $2004,27.4 \%$ in $2005,22.8 \%$ in 2006 and $21.9 \%$ in 2007 (Table 6).

Poisonings with gases, including carbon monoxide, were the third most frequent cause, accounting for $5.9 \%$ of total number of poisonings in $2003,7.0 \%$ in $2004,5.7 \%$ in 2005, 7.7\% in 2006, and 7.9\% in 2007 (Table 6).

Poisonings with street drugs and pesticides should be mentioned as the significant causes of poisoning in the analyzed material. Figure 2 shows poisonings in 2003-2007 arranged according to substance responsible for the event. Causes of poisonings according to underlying circumstances of event are illustrated by Figure 3. Suicidal attempts were the most frequent condition during 2003. They were followed by poisonings associated with substance abuse, including dependence-related abuse and constituted $23.7 \%$ of total number of the cases.

The accidental poisonings were situated on the third place with $14.1 \%$.

During 2004-2007, the poisonings were most frequently due to drug abuse or dependence and accounted for $32.9 \%$ of total number of pts in 2004; $36.8 \%$ in 2005; $33.2 \%$ in 2006; $35.9 \%$ in 2007, respectively. Suicidal poisonings occurred less frequently, with a percentage of $29.4 \%$ in 2004; $28.0 \%$ in $2005 ; 28.4 \%$ in $2006 ; 26.5 \%$ in 2007 (Figure 3). Accidental poisonings, similarly as in the 2003, were third in frequency, with $12.0 \%$ in $2004 ; 10.9 \%$ in $2005 ; 17.9 \%$ in 2006 and $18.0 \%$ in 2007, respectively (Figure 3).

Nine deaths due to poisonings were recorded in $\mathrm{TU}$ during 2003, whereas 14 fatal cases were noted in 2004, 6 in 2005, 17 in 2006 and 7 in 2007, respectively. Poisoning with pharmaceuticals constituted the most frequent cause of death in 2003-2005 and remained an important etiologic factor of mortality during 2006-2007, when it was responsible for the second highest number of deaths. Intoxication with alcohols was the most frequent event leading to death during that period. Other fatalities resulted from glycols, pesticides and carbon monoxide (Table 1-5).

The age of patients constitutes another parameter evaluated in this study. During examined period, the largest age group consisted of the patients at the age

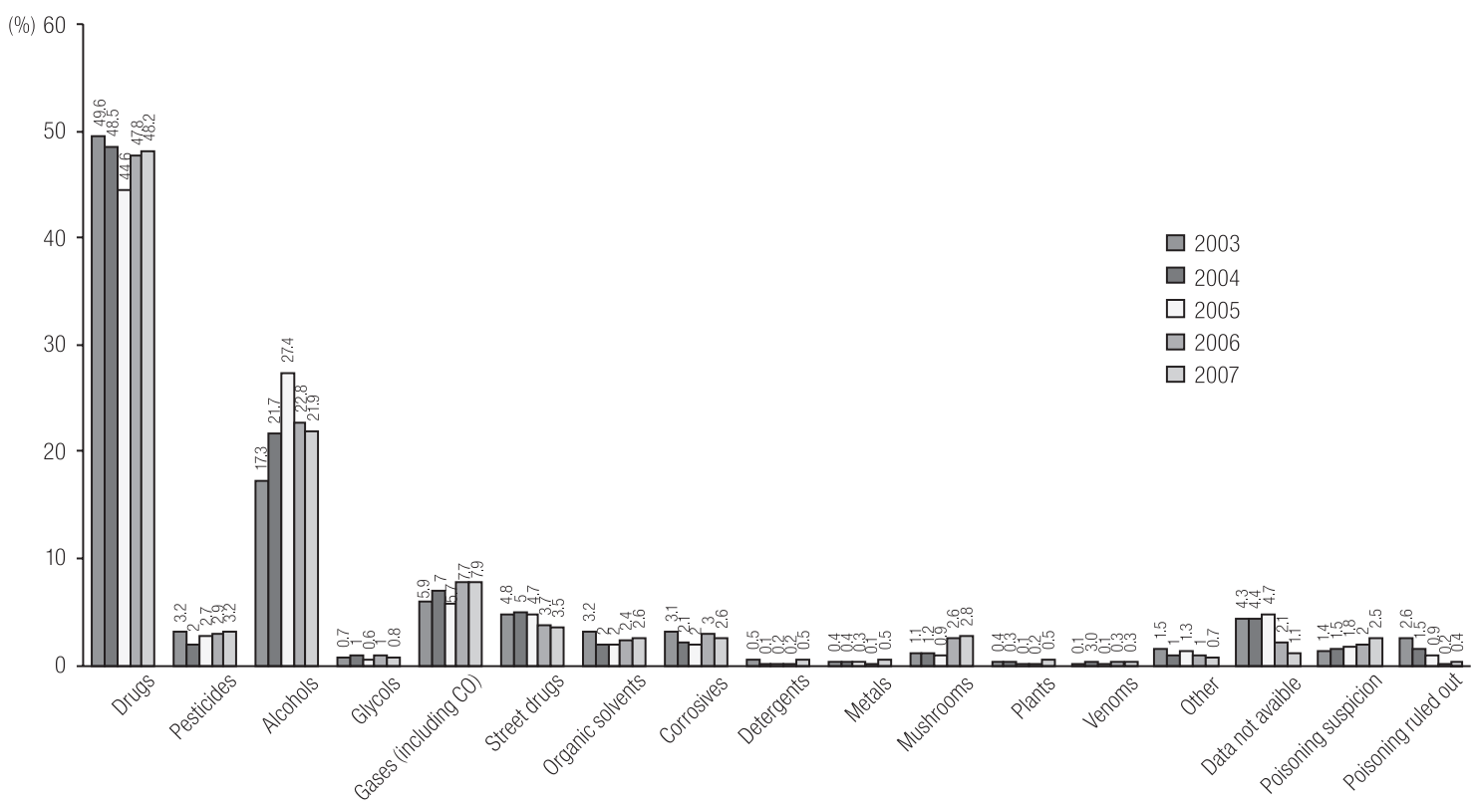

Fig. 2. Distribution of poisonings according to the toxic agent in Łódź, 2003-2007. 


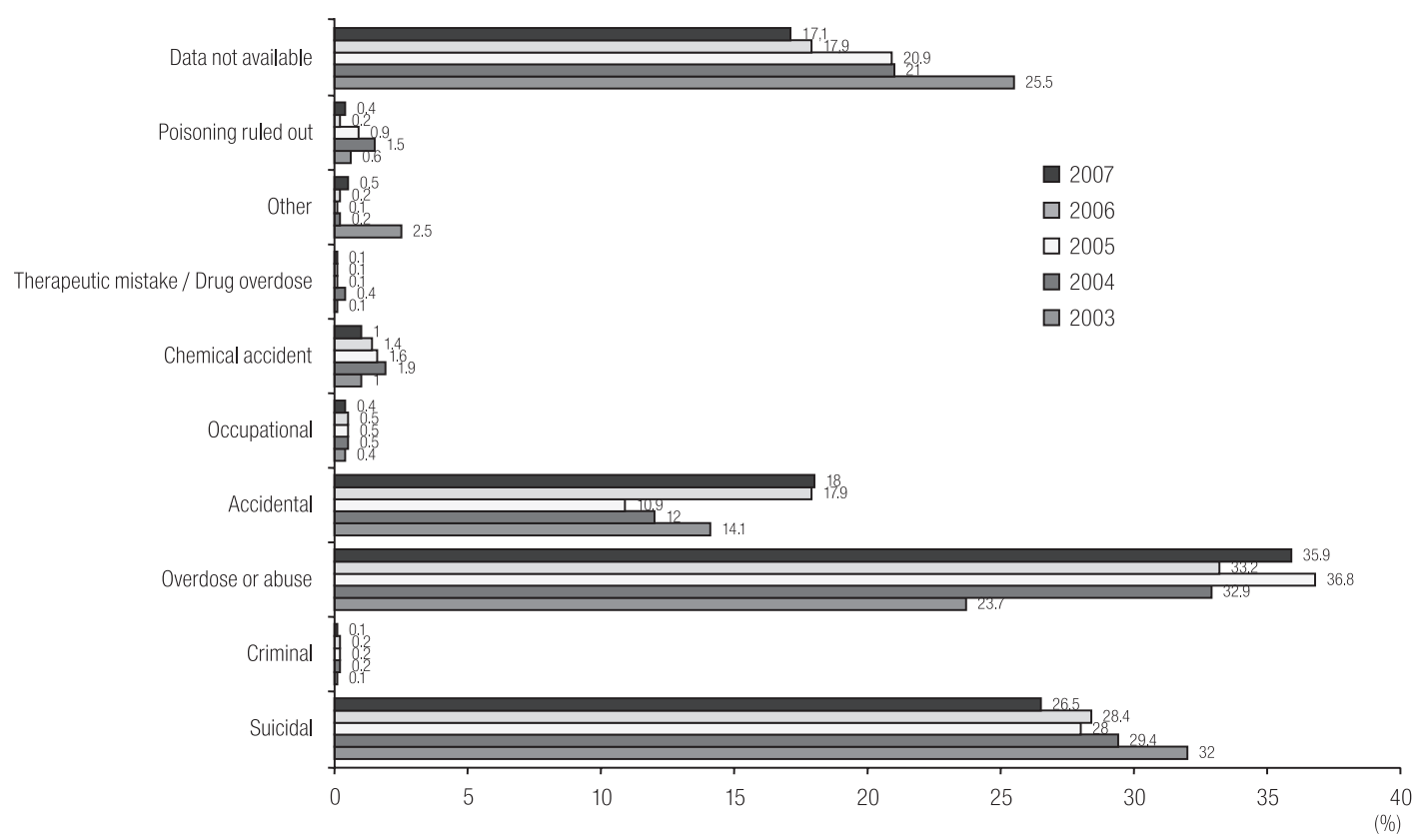

Fig. 3. Types of poisonings in Łódź, 2003-2007.

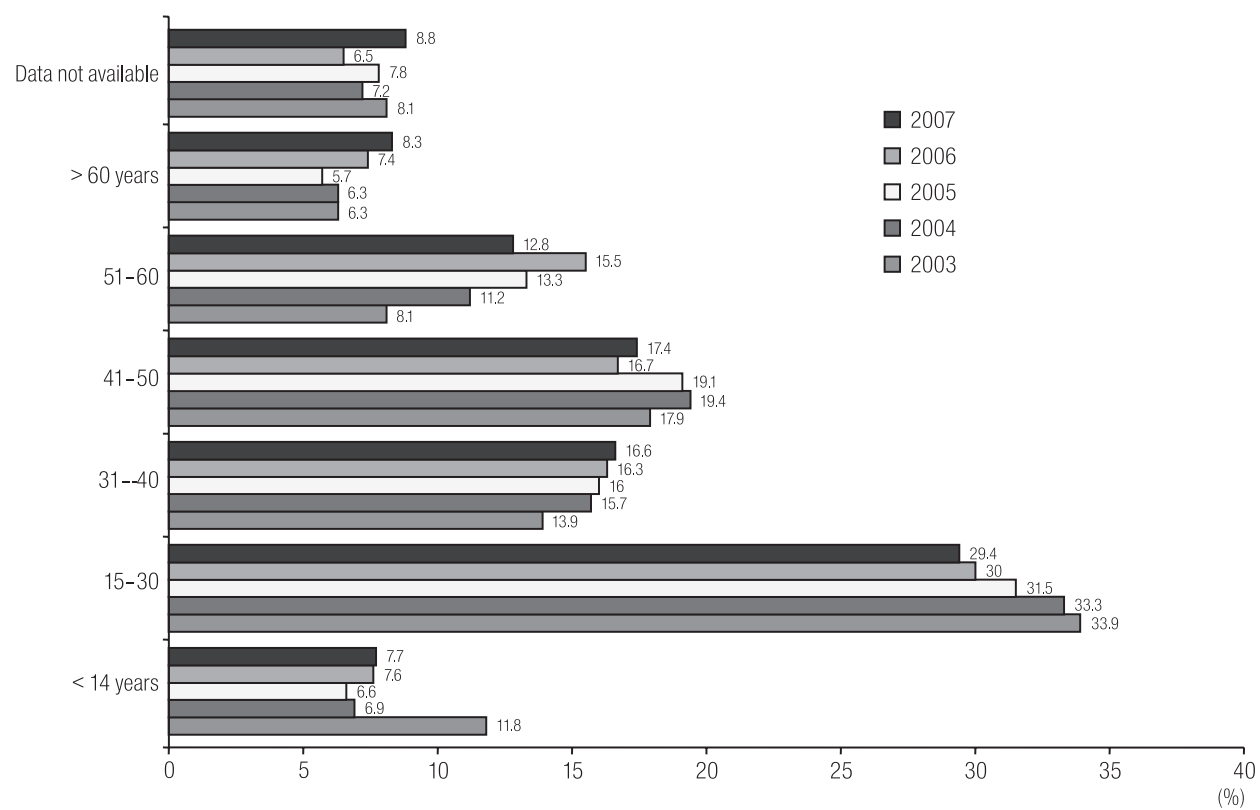

Fig. 4. Distribution of poisonings according to the patients' age in Lódź, 2003-2007.

of 15-30 years: $2003-33.9 \%$; $2004-33.3 \%$; $2005-$ $31.5 \% ; 2006-30 \% ; 2007-29.4 \%$. The second largest age bracket $41-50$ years was represented in the $17.9 \%$ of cases during 2003, in $19.4 \%$ during 2004, in $19.1 \%$ during 2005, in $16.7 \%$ during 2006 and in $17.4 \%$ during 2007 , respectively. Age group of 31-40 years composed the third most frequent category with $13.9 \%$ of all cases in $2003,15.7 \%$ in $2004,16.0 \%$ in $2005,16.3 \%$ in 2006 and $15.6 \%$ in 2007, respectively. Figure 4 shows total number of recorded cases classified according to age. 


\section{DISCUSSION}

Our results show that both the number of patients treated in TU in Łódź and the number of phone enquiries decreased during the analyzed period. In our opinion, a significant part of patients, presenting with mild symptoms of acute poisoning (without any complications), is managed within other hospitals each year. This assumption may explain the fall in number of patients treated directly in TU. Additionally, unknown precisely number of toxicology phone enquiries are served by regional toxicology information centers, geographically corresponding with respective district hospitals. Analysis of registered data revealed that medications were the most frequent etiologic factors underlying hospitalizations due to poisonings during the period 2003-2007. A prospective study on the incidence of acute poisoning in South Africa also confirmed that pharmaceuticals accounted for the majority of hospitalized cases, being responsible for $76 \%$ of all admissions (the total number of patients was 662) [5]. The study from Bulgaria, describing the epidemiology of self-poisoning in that country, confirmed that medicines made up the leading type of toxic agent in this cohort with 350 patients $(97.2 \%)$ after ingestion of multiple medicines [6]. Similar conclusions come from epidemiological study about acute poisonings in Azerbaijan. It revealed that in $31.9 \%$ of all acute poisoning cases, the patients were poisoned by pharmaceuticals [7]. Medicines also proved to be the most frequent group of chemical substances responsible for more than $50 \%$ of all hospital admissions due to acute poisonings in a large retrospective study on acute poisonings in Poland during 1970-2000 [8]. Data collected for the purpose of this work by Kotwica and Czerczak from NPIC were obtained from individual concerned institutions (hospitals), and also from the regional Poison Information Centers in towns such as Łódź, Kraków, Gdańsk, Poznań, Sosnowiec, Rzeszów, Warszawa, Wrocław [8].

Other toxic substances such as alcohol and carbon monoxide constitute also important causes of poisonings during evaluated period. According to the literature data published by Nofer Institute of Occupational Medicine in the following years: 1980; 1995;1984; 1994; 2002 [9-12], the contribution of alcohol poisonings increased from $10.5 \%$ of total number of cases in 1987 to the value above 20\% after 1990. Alcohol is a factor that not only encourages people to intentional self poisoning but is also perceived by the patients as a way of escaping from problems. In Suokas and Lonnqvist's data, $62 \%$ of parasuicides were related to alcohol abuse [13]. Furthermore, some authors show that there is an association between alcoholism and depressive disorders that may contribute to suicidal behavior [14]. Poisonings with carbon monoxide ranged from 5.7\% in 2005 to $7.9 \%$ in 2007 .

The main event underlying carbon monoxide poisoning was dysfunction of ventilation systems in dwelling houses. Street drugs and pesticides continue to be the significant causes of acute poisonings. According to the authors, the changes in society and family resulting from urbanization for over the last century may be responsible for the increase in the drug street abuse within the modern community.

Pesticides are still an important cause of acute poisonings; however, it is important to mention that, recently, organophosphorous pesticides, associated usually with high mortality, have been replaced by less toxic pyretroids. Unlike in Poland, pesticides in developing world are still a big problem; frequency of pesticide poisonings in that region continues to be high [15].

Suicidal poisonings formed the largest group in 2003, whereas during 2004-2007, poisonings related to the abuse, including dependence-related abuse, were most frequent. The dramatic increase in the number and availability of therapeutic drugs may have contributed to the high proportion of drug dependence.

An analysis of the poisoning-related mortality indicated that medicines and alcohol were responsible for the majority of fatal cases. 
Patients between 15 and 30 constituted the largest group in comparison with other age brackets. Young people are the group of patients that are more prone to practise riskseeking behaviours. We have also noticed that poor school performance may be partially associated with the higher frequency of acute poisoning among these patients.

\section{CONCLUSIONS}

The number of patients treated in TU in Łódź increased during 2003-2005, then subsequently decreased during 2006-2007; the number of consultations given by phone systematically decreased during the analyzed period; the most frequent causes of poisonings were as follows: medications, alcohols, gases (including CO), drugs of abuse and pesticides; suicidal poisonings constituted the largest group in 2003, whereas during 2004-2007 poisonings caused by abuse, including dependence-related abuse were most frequent; patients between 15 and 30 years old constituted the largest age group within the evaluated cohort.

\section{REFERENCES}

1. Centers for Disease Control and Prevention. Poisoning in the United States: fact sheet [cited: 2011 Jan 12]. Available from URL: http://www.cdc.gov/ncipc/factsheets/poisoning.htm.

2. Brvar M, Slana M, Mozina H, Mozina M. Admissions to the Medical Emergency Department due to Intentional Medication Overdoses, Medication Errors and adverse drug reactions. Clin Toxicol 2010;48:257(abstract 73).

3. Jacobsen D, Frederichsen PS, Knutsen KM, Sørum Y, Talseth T, Ødegaard OR. A prospective study of 1212 cases of acute poisoning: general epidemiology. Hum Toxicol 1984;3:93-106.
4. Davanzo F, Vignally P, Settimi L. Suicide attempt by poisoning in Italy: a preliminary characterization. Clin Toxicol 2009;47:477(abstract 158).

5. Veale DJH, Wium CA, Muller GJ. A prospective study of the incidence and spectrum of acute poisonings in South Africa based on hospital admission and poison information centre data. Clin Toxicol 2010;48:284(abstract).

6. Radenkova-Saeva JV, Vanev PI. Suicidal self-poisoning one year epidemiological study. Clin Toxicol 2009;47:505 (abstract 272).

7. Afandiyev IN. Epidemiology of acute chemical poisonings in Azerbaijan. Clin Toxicol 2009;47:505(abstract 275).

8. Kotwica M, Czerczak S.Acute poisonings registered since 1970: trends and characteristics. Analysis of the files collected in the national Poison Information Centre, Łódź, Poland. Int J Occup Med Environ Health 2007;20(1):38-43.

9. Bogdanik T, Jaraczewska W, Szymanska S. An analysis of the causes and course of acute poisonings in toxicological center. Stud Mat Monogr 1980;1:14-34 [in Polish].

10. Czerczak S, Jaraczewska W. Acute poisonings in Poland. J Toxicol Clin Toxicol 1995;33:669-75.

11. Jaraczewska W. Acute poisonings structure in 1969-1982. Zesz Metod Org IMP Łódź 1984;2-3:139-49 [in Polish].

12. Kotwica M, Rogaczewska A. Acute poisonings in Poland during the period 1997-1999. An analysis of files from the National poison Information Centre. Przegl Lek 2002;59(4-5): 318-24 [in Polish].

13. Suokas J, Lonnqvist J. Suicide attempts in which alcohol is involved. Acta Psychiatr Scand 1995;91:36-40.

14. Berman AL, Silverman MM. Comprehensive textbook of suicidology. New York: The Guilford Press; 2000.

15. Eddleston M. Patterns and problems of deliberate self-poisoning in the developing world. QJM 2000;93(11):715-31.

This work is available in Open Access model and licensed under a Creative Commons Attribution-NonCommercial 3.0 Poland License - http://creativecommons.org/ licenses/by-nc/3.0/pl/deed.en. 